\title{
Volume 9, Issue 1, Formation
}

\section{Taif Alawsi ${ }^{1}$, Hayder A. L. Mossa ${ }^{2}$}

\section{${ }^{1}$ Department of Information Engineering, Electronics and}

Telecommunications, Sapienza University of Rome, Rome, Italy.

taif.alawsi@outlook.com, taif.alawsi@uniroma1.it

${ }^{2}$ High Institute of Infertility Diagnosis and Assisted Reproductive

Technologies, Al Nahrain University, Baghdad, Iraq.

haydermossa@googlemail.com

\section{Abstract}

The editors of the Iraqi Journal of Embryos and Infertility Researches (IJEIR) are thankful to the huge efforts made by the reviewers in peerreviewing the submitted manuscripts. Thanks to their efforts the first issue of the $9^{\text {th }}$ volume is now available online with open access to the articles content. We are looking forward in inclusion in relevant indexing in the near future. We would like to acknowledge the reviewers for their contribution, and we wish them the greatest success. We ensured the anonymity of both reviewers and authors and followed a double-blind peer-review procedure. Our published articles are under the creative common attribution license. We strictly followed the COPE ethical code in the published studies. Our articles are published under the Creative Commons Attribution 4.0 International License which permits use, sharing, adaptation, distribution and reproduction in any medium or format, as long as you give appropriate credit to the original author(s) and the source, provide a link to the Creative Commons license, and indicate if changes were made. http://creativecommons.org/licenses/by/4.0/ 
IrAOIJOURnal of Embryos ANd I NFERTILITY RESEARCHES

Alawsi and Mossa, Vol. 9, Issue 1, Pp. e1-e10, (2019)

DOI: http://doi.org/10.28969/IJEIR.v9.i1.e1

E-ISSN: 2616-6984 P-ISSN: 2218-0265

\section{Our Reviewers}

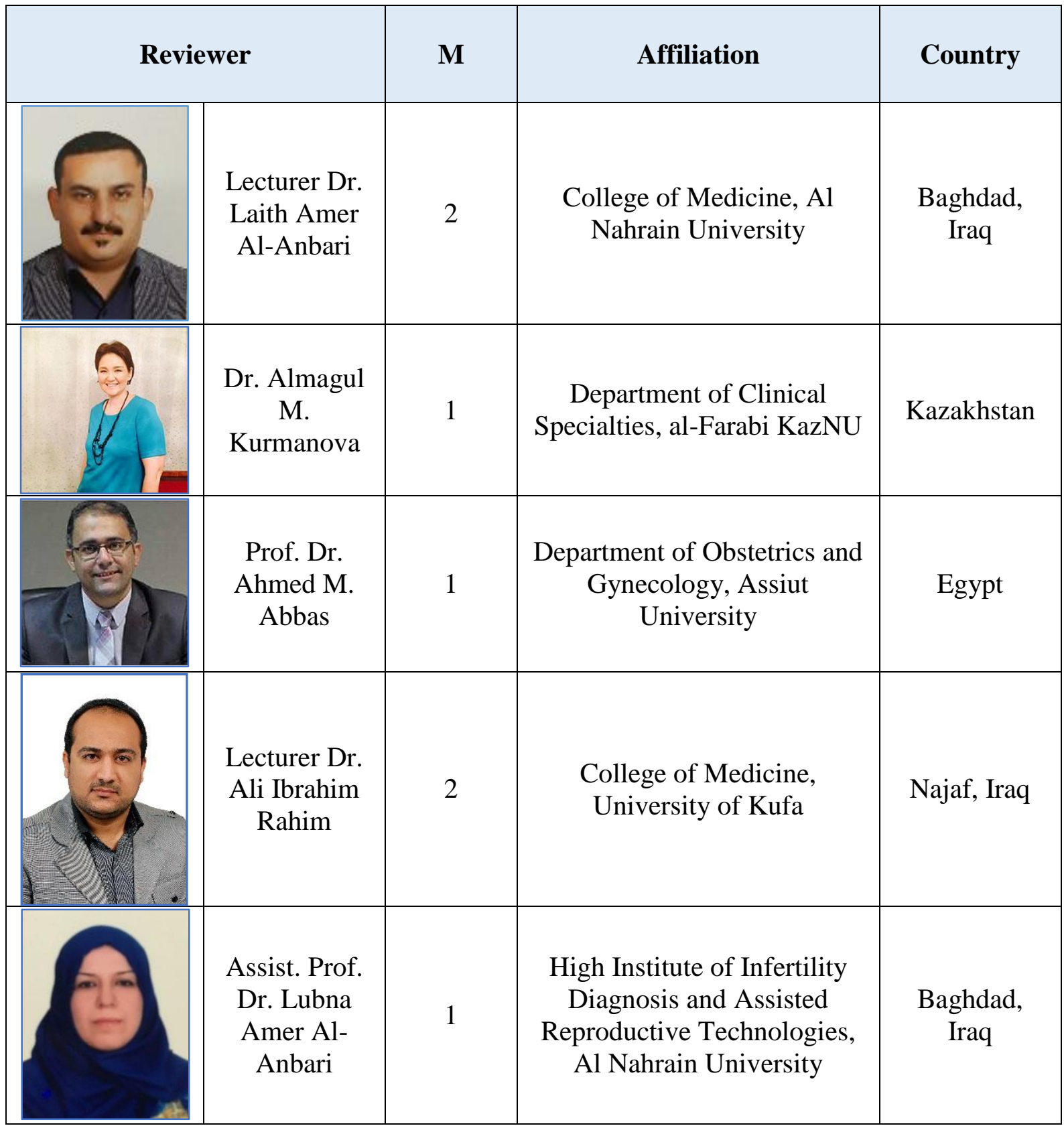


IrAOIJOURnal of Embryos ANd I NFERTILITY RESEARCHES

Alawsi and Mossa, Vol. 9, Issue 1, Pp. e1-e10, (2019)

DOI: http://doi.org/10.28969/IJEIR.v9.i1.e1

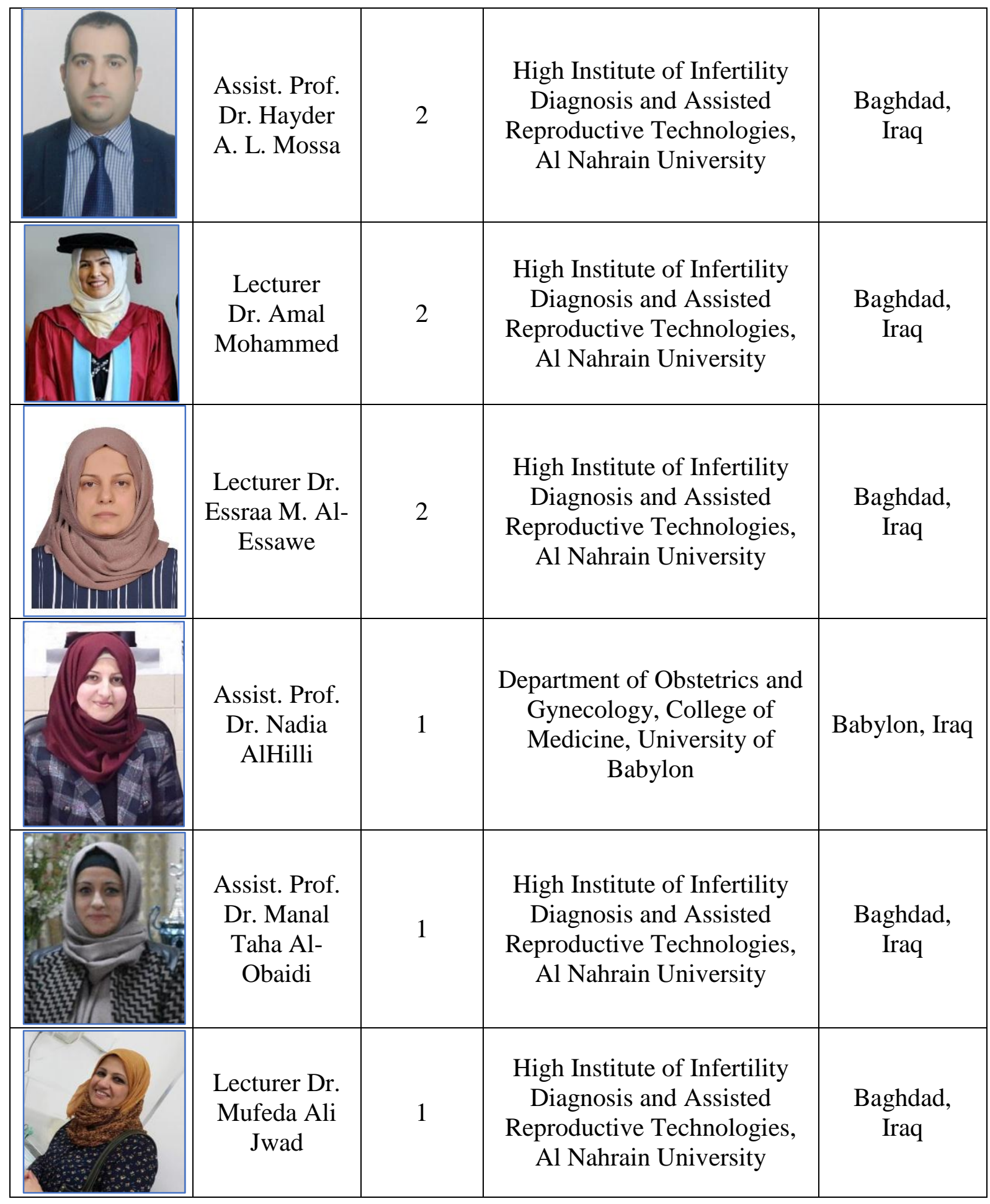


IrAOIJOURnal of Embryos ANd I NFERTILITY RESEARCHES

Alawsi and Mossa, Vol. 9, Issue 1, Pp. e1-e10, (2019)

DOI: http://doi.org/10.28969/IJEIR.v9.i1.e1

E-ISSN: 2616-6984 P-ISSN: 2218-0265

\section{Our Authors}

\begin{tabular}{|c|c|c|c|}
\hline lor & $\mathbf{M}$ & Affiliation & Country \\
\hline $\begin{array}{l}\text { Reem Qays } \\
\text { Mohammed } \\
\text { Wafeeq }\end{array}$ & 1 & $\begin{array}{l}\text { High Institute of Infertility } \\
\text { Diagnosis and Assisted } \\
\text { Reproductive Technologies, } \\
\text { Al Nahrain University }\end{array}$ & $\begin{array}{l}\text { Baghdad, } \\
\text { Iraq }\end{array}$ \\
\hline $\begin{array}{l}\text { Dr. Khitam } \\
\text { Malik Abdul- } \\
\text { Hameed }\end{array}$ & 1 & $\begin{array}{l}\text { High Institute of Infertility } \\
\text { Diagnosis and Assisted } \\
\text { Reproductive Technologies, } \\
\text { Al Nahrain University }\end{array}$ & $\begin{array}{l}\text { Baghdad, } \\
\text { Iraq }\end{array}$ \\
\hline $\begin{array}{l}\text { Dr. Ezdehar } \\
\quad \text { N. Ali }\end{array}$ & 1 & $\begin{array}{l}\text { High Institute of Infertility } \\
\text { Diagnosis and Assisted } \\
\text { Reproductive Technologies, } \\
\text { Al Nahrain University }\end{array}$ & $\begin{array}{l}\text { Baghdad, } \\
\text { Iraq }\end{array}$ \\
\hline $\begin{array}{c}\text { Zahrah Saleh } \\
\text { Mahdi Ali }\end{array}$ & 1 & $\begin{array}{l}\text { High Institute of Infertility } \\
\text { Diagnosis and Assisted } \\
\text { Reproductive Technologies, } \\
\text { Al Nahrain University }\end{array}$ & $\begin{array}{l}\text { Baghdad, } \\
\text { Iraq }\end{array}$ \\
\hline $\begin{array}{l}\text { Prof. Dr. } \\
\text { Mohammad } \\
\text { Oda Selman }\end{array}$ & 2 & $\begin{array}{l}\text { High Institute of Infertility } \\
\text { Diagnosis and Assisted } \\
\text { Reproductive Technologies, } \\
\text { Al Nahrain University }\end{array}$ & $\begin{array}{l}\text { Baghdad, } \\
\text { Iraq }\end{array}$ \\
\hline
\end{tabular}


IrAOIJOURnal of Embryos ANd I NFERTILITY RESEARCHES

Alawsi and Mossa, Vol. 9, Issue 1, Pp. e1-e10, (2019)

DOI: http://doi.org/10.28969/IJEIR.v9.i1.e1




IRAOIJOURnal of Embryos ANd I NFERTILITY ReseArChes






\section{Our Articles}

\begin{tabular}{|c|c|c|}
\hline Title & Keywords & Link \\
\hline $\begin{array}{l}\text { Assessment Quality of Selected } \\
\text { Sperm During Glass Wool and } \\
\text { Sephadex Filtration Techniques in } \\
\text { Infertile Men }\end{array}$ & $\begin{array}{c}\text { Sephadex, } \\
\text { Asthenozoospermia, Sperm } \\
\text { Preparation Technique }\end{array}$ & $\begin{array}{l}\text { http://doi.org/10.28 } \\
\text { 969/IJEIR.v9.i1.r1 }\end{array}$ \\
\hline $\begin{array}{l}\text { The New Approach of Hyaluronic } \\
\text { Binding Assay in Relevance to } \\
\text { Sperm Activation by Direct Swim-up } \\
\text { Technique in Iraqi Infertile Men }\end{array}$ & $\begin{array}{c}\text { Hyaluronic Acid, Bound } \\
\text { Sperm, direct swim-up } \\
\text { technique, } \\
\text { normozoospermia } \\
\end{array}$ & $\begin{array}{l}\text { http://doi.org/10.28 } \\
\text { 969/IJEIR.v9.i1.r2 }\end{array}$ \\
\hline $\begin{array}{c}\text { Clinical Role of Follicle Stimulating } \\
\text { Hormone, Luteinizing Hormone and } \\
\text { Testosterone as Predictive Markers } \\
\text { of Sperm Yield by Testicular Biopsy } \\
\text { in Azoospermic Patients }\end{array}$ & $\begin{array}{l}\text { Testicular biopsy; } \\
\text { Histopathology; } \\
\text { Reproductive hormones; } \\
\text { Sperm retrieval }\end{array}$ & $\begin{array}{l}\text { http://doi.org/10.28 } \\
\text { 969/IJEIR.v9.i1.r3 }\end{array}$ \\
\hline $\begin{array}{l}\text { Comparative Study Between the } \\
\text { Explained and Unexplained Patient } \\
\text { Women with Recurrent Miscarriage }\end{array}$ & $\begin{array}{l}\text { Recurrent miscarriage, } \\
\text { Abortion }\end{array}$ & $\underline{\text { http://doi.org/10.28 }}$ \\
\hline $\begin{array}{c}\text { Early and Short Follicular GnRH } \\
\text { Antagonist (Sandwich) Protocol } \\
\text { Versus Conventional GnRH } \\
\text { Antagonist Protocol in Normal } \\
\text { Responders }\end{array}$ & $\begin{array}{c}\text { GnRH antagonist, MII } \\
\text { oocyte, follicles and embryo } \\
\text { numbers }\end{array}$ & $\begin{array}{l}\text { http://doi.org/10.28 } \\
\text { 969/IJEIR.v9.i1.r5 } \\
\end{array}$ \\
\hline $\begin{array}{l}\text { Predictors for Response to Letrozole } \\
\text { as an Ovulation Induction in } \\
\text { Anovulatory Infertile Polycystic } \\
\text { Ovarian Syndrome Women }\end{array}$ & $\begin{array}{c}\text { Letrozole, Polycystic } \\
\text { ovarian syndrome (PCOS), } \\
\text { infertility }\end{array}$ & $\begin{array}{l}\text { http://doi.org/10.28 } \\
\text { 969/IJEIR.v9.i1.r6 }\end{array}$ \\
\hline $\begin{array}{l}\text { Comparing the Activation Role of } \\
\text { Centrifugation Swim-up and the } \\
\text { Density Gradient Combined with } \\
\text { ALLGrad Sperm Preparation } \\
\text { Techniques }\end{array}$ & $\begin{array}{c}\text { Seminal fluid analysis, } \\
\text { Sperm activation } \\
\text { techniques, Centrifugation } \\
\text { swim-up techniques, } \\
\text { Density gradient technique, } \\
\text { ALLGrad solution }\end{array}$ & $\underline{\text { http://doi.org/10.28 }}$ \\
\hline $\begin{array}{c}\text { Evaluation of Serum Progesterone } \\
\text { Level on the Day of hCG Injection } \\
\text { on Clinical Outcome of Antagonist } \\
\text { Protocol in ICSI Cycles }\end{array}$ & $\begin{array}{l}\text { hCG; ICSI; Progesterone } \\
\text { (P4); PPR; antagonist } \\
\text { protocol }\end{array}$ & $\begin{array}{l}\text { http://doi.org/10.28 } \\
\text { 969/IJEIR.v9.i1.r8 }\end{array}$ \\
\hline
\end{tabular}




\section{Reviewers}

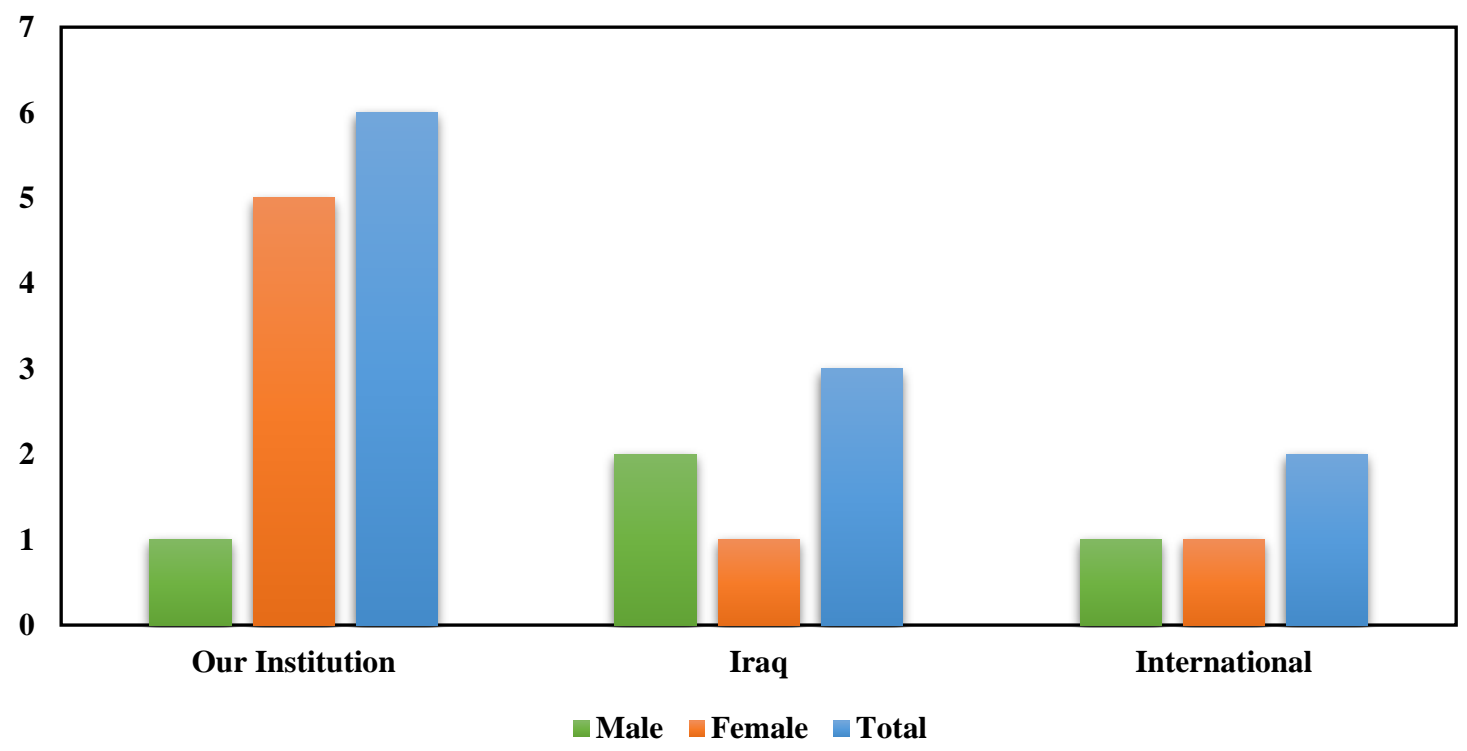

Figure (1): Contributed reviewers

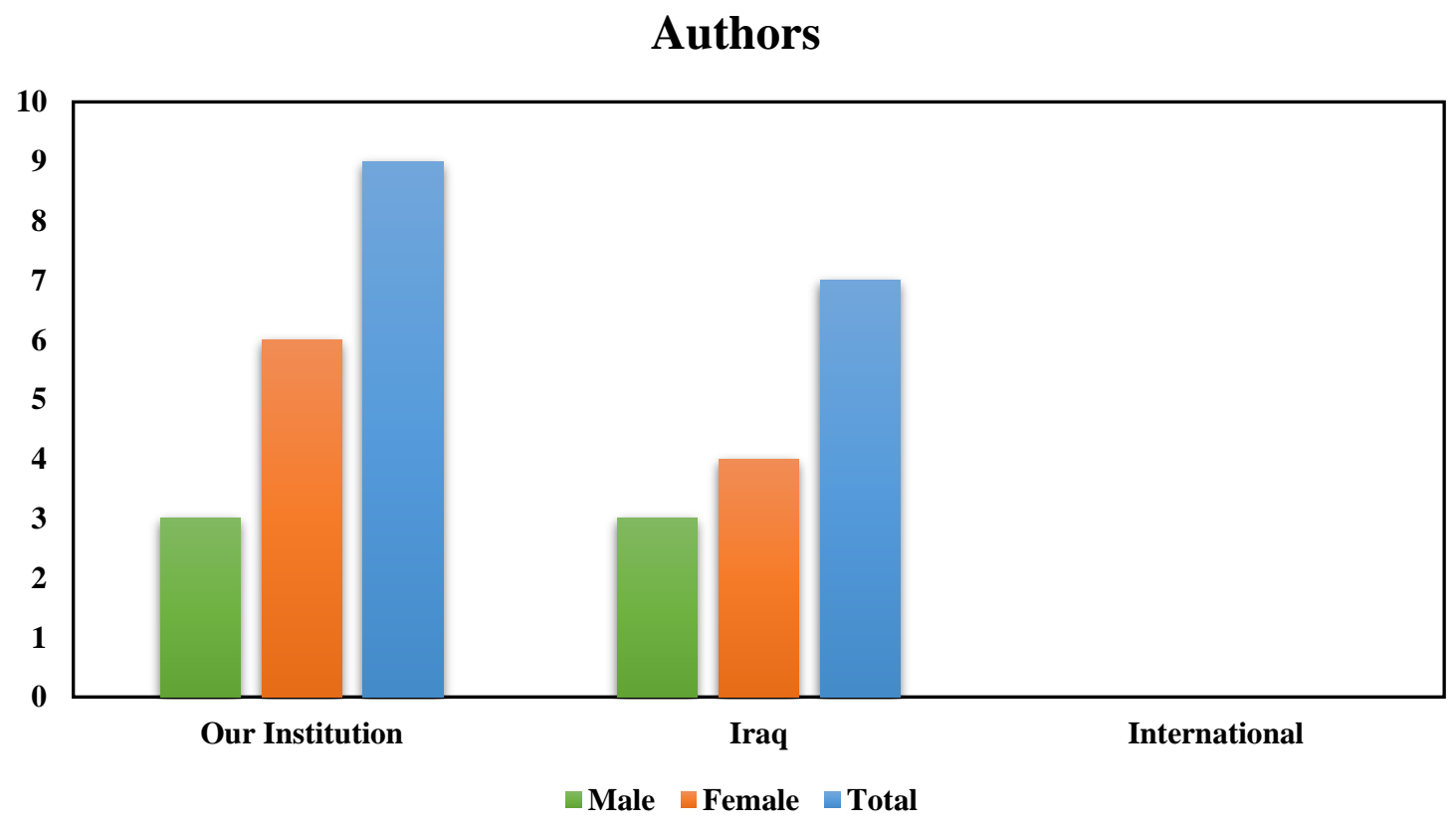

Figure (2): Contributed authors 






Figure (3): Editorial management scheme

\section{Acknowledgment}

We would like to thank all authors, reviewers, and journal staff for their contribution.

\section{Biography}

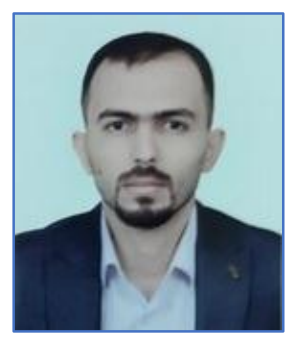

\section{Taif Alawsi}

He was born in Baghdad, Iraq, in 1992. He received the B.Sc. and the M.Sc. degrees in Laser and Optoelectronics Engineering from Al Nahrain University, Baghdad, Iraq, in 2013, and 2017, respectively. He is a Ph.D. student at the University of Baghdad, Institute of Laser for Postgraduate Studies, Electronics and Communication Engineering. Currently, he is a Ph.D. Researcher at the Sapienza University of Rome, Rome, Italy. His work experience is in the fields of Communication and Telecommunication Systems, Medical Instrumentations, and Laboratory Equipment. His publications include a Research article, a Review article, a Book, and a Thesis. He had numerous scientific activities such as workshops, presentations, online classes and conferences. $\mathrm{He}$ is actively a certified reviewer for Web of Science and Scopus indexed journals including IEEE Photonics Journal, IET Microwaves, Antennas \& Propagation, Electronics Letters, Micro \& Nano Letters, Optical Engineering (SPIE), Advances in Science, Technology and Engineering Systems Journal (ASTESJ). He is a member of several global academic societies including IEEE, IEEE 


\section{IraOIJ OURnal of Embryos and I NFERTILITY Researches}

Photonics Society, American Chemical Society, Optical Society of America, Italian Society of Optics and Photonics, and Iraqi Engineering Union. He received the Google Certified Educator: Level 1. He is currently the editorial manager of the Iraqi Journal of Embryos and Infertility Researches (IJEIR). His current work includes smartphone sensors for medical applications. His research interests include Optics, Lasers, Photonics, Solar cells, Graphene, Smartphone Sensors, and Image Processing.

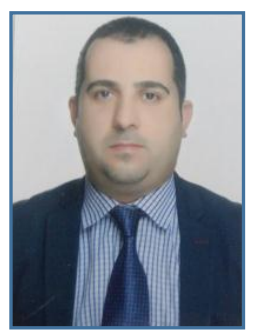

\section{Dr. Hayder A. L. Mossa}

He is an assistant professor at Al Nahrain University. He is a member of the Iraqi Society of Fertility, Iraqi Society of Zoonotic Diseases (ISZD) \& Iraqi Zoonotic Communicable Diseases (ISZCD), Iraqi Academics Syndicate, European Society of Human Reproduction and Embryology (ESHRE). An editorial board member of Merit Research Journal of Medicine and Medical Sciences (MRJMMS), International Journal of Medical Research \& Health Sciences (IJMRHS). A reviewer at global journals Inc. (USA). He was a candidate for the award of Arabian Young Researchers in 2007. He granted for many appreciation certificates in the scientific \& administrative fields. He participated \& supervised in more than 60 scientific \& medical conferences, workshops \& training course. Has many kinds of research $\&$ articles published in Iraqi \& national medical journals. Chief \& member of nearly 60 scientific \& administrative committees from 2006-till now. Has interests in assisted reproductive technologies, reproductive micromanipulation, medical terminology, research methods and seminars, reproductive physiology, advanced embryology.

\section{How to cite:}

Alawsi T, Mossa HAL. Volume 9, Issue 1, Formation; Iraqi Journal of Embryos and Infertility Researches (IJEIR), (2019);9(1):e1-e10. Doi: http://doi.org/10.28969/IJEIR.v9.i1.e1



This article is licensed under a Creative Commons Attribution 4.0 International License, which permits use, sharing, adaptation, distribution and reproduction in any medium or format, as long as you give appropriate credit to the original author(s) and the source, provide a link to the Creative Commons license, and indicate if changes were made. http://creativecommons.org/licenses/by/4.0/. 